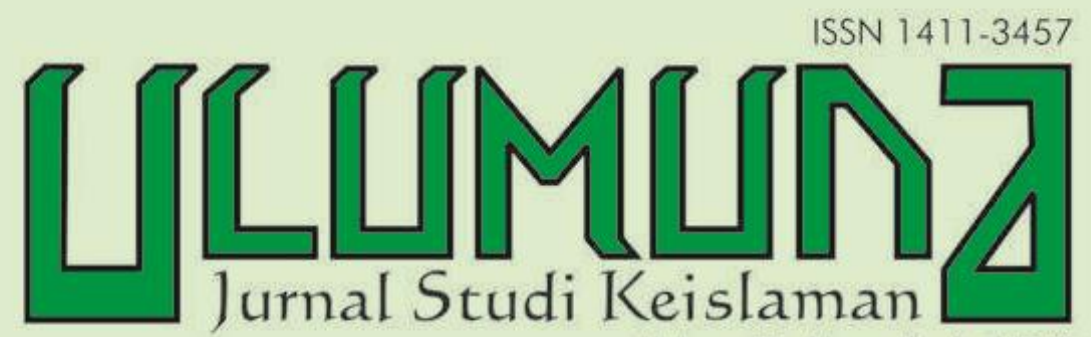

Volume $17 \cdot$ Nomor $1 \cdot$ Juni 2013

TERAKREDITASI B: SK Dirjen Dikti Kemdikbud Nomor: 56/DIKTI/Kep/2012, Tanggal 24 Juli 2012

MENCERNA AKAR FILSAFAT DALAM ISLAM Ismail Fahmi Arrauf PERKEMBANGAN PARADIGMA EPISTEMOLOGI DALAM FILSAFAT ISLAM Fathul Mufid EPISTEMOLOGI ISLAM: KEDUDUKAN WAHYU SEBAGAI SUMBER ILMU Anwar Muiahidin DARI ISLAMISASI ILMU MENUJU PENGILMUAN ISLAM: MELAWAN HEGEMONI EPISTEMOLOGI BARAT Ismail Toib dan Mukhlis INDUKTIVISME SEBAGAI BASIS PENGEMBANGAN ILMU PENGETAHUAN DALAM ISLAM Masdar Hilmy

PERTAUTAN ONTOLOGI FILSAFAT DAN TASAWUF: PERSPEKTIF TENTANG RELASI TUHAN, MANUSIA, DAN ALAM Hadarah Rajab PERTAUTAN EPISTEMOLOGI FILSAFAT DAN TASAWUF: TELAAH SISTEM PEMIKIRAN ABDUL HALIM MAHMUD Lalu Muchsin Effendi ETIKA DALAM FILSAFAT ISLAN:

PEMIKIRAN FILOSOF MUSLIM TENTANG KEBAHAGIAAN Mustain PEngembangan Sumber Daya MANusia DALAM PERSPEKTIF EPESTIMOLOGI FILSAFAT ISLAM Asep Kumiawan 


\section{DAFTAR ISI}

\section{Pedoman Transliterasi}

1-18 • Ismail Fahmi Arrauf,

"Mencerna Akar Filsafat dalam Islam"

19-40 • Fathul Mufid,

"Perkembangan Paradigma Epistemologi

dalam Filsafat Islam"

41-64 • Anwar Mujahidin

"Epistemologi Islam:

Kedudukan Wahyu Sebagai Sumber Ilmu"

65-96 • Ismail Toib dan Mukhlis

"Dari Islamisasi Ilmu Menuju Pengilmuan Islam:

Melawan Hegemoni Epistemologi Barat"

97-126 • Masdar Hilmy

"Induktivisme Sebagai Basis Pengembangan

Ilmu Pengetahuan dalam Islam"

127-152 • Hadarah Rajab

"Pertautan Ontologi Filsafat dan Tasawuf:

Telaah Relasi Tuhan, Manusia, dan Alam"

153-190 • Lalu Muchsin Effendi

"Pertautan Epistemologi Filsafat dan Tasawuf:

Telaah Sistem Pemikiran Abdul Halim Mahmud"

191-212• Mustain

"Etika dan Ajaran Moral Filsafat Islam:

Pemikiran Para Filosof Muslim tentang Kebahagiaan"

\section{3-230 • Asep Kurniawan}

Pengembangan Sumber Daya Manusia

dalam Perspektif Epestimologi Filsafat Islam

\section{APENDIKS}




\section{PEDOMAN TRANSLITERASI}

\begin{tabular}{|c|c|c|c|c|c|c|}
\hline 1 & $=$ & $\mathbf{a}$ & $\dot{\varepsilon}$ & $\dot{\varepsilon}$ & $=$ & $\mathrm{g}$ \\
\hline ب & $=$ & b & & ف & $=$ & $\mathrm{f}$ \\
\hline 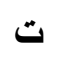 & $=$ & $\mathrm{t}$ & & ق & $=$ & $q$ \\
\hline$\dot{H}$ & $=$ & th & & ك5 & $=$ & $\mathbf{k}$ \\
\hline ج & $=$ & $\mathfrak{j}$ & & J & $=$ & 1 \\
\hline$\tau$ & $=$ & h & & م & $=$ & $\mathrm{m}$ \\
\hline$\dot{\tau}$ & $=$ & $\mathbf{k h}$ & & ن & $=$ & $\mathbf{n}$ \\
\hline د & $=$ & d & & و & $=$ & $\mathbf{w}$ \\
\hline j & $=$ & dh & 。 & 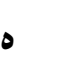 & $=$ & $\mathbf{h}$ \\
\hline J & $=$ & $\mathbf{r}$ & & $\varepsilon$ & $=$ & , \\
\hline j & $=$ & $\mathrm{z}$ & & ي & $=$ & $\mathbf{y}$ \\
\hline س & $=$ & $\mathrm{s}$ & & & & \\
\hline 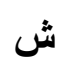 & $=$ & sh & \multicolumn{4}{|c|}{ Untuk Madd dan Diftong } \\
\hline ص & $=$ & ș & $i=$ & $=$ & \multicolumn{2}{|c|}{$\bar{a}$ (a panjang) } \\
\hline 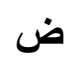 & $=$ & d & 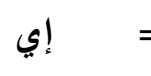 & $=$ & \multicolumn{2}{|c|}{$\overline{1}$ (i panjang) } \\
\hline b & $=$ & $t$ & 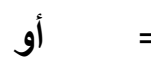 & $=$ & \multicolumn{2}{|c|}{$\bar{u}$ (u panjang) } \\
\hline ظ & $=$ & $z$ & او او & $=$ & \multicolumn{2}{|c|}{ aw } \\
\hline$\varepsilon$ & $=$ & 6 & أي اي & $=$ & \multicolumn{2}{|l|}{ ay } \\
\hline
\end{tabular}

Contoh penulisan dengan transliterasi:

اعوذ بالله من الشيطان الرجيم (a'üdhu bi al-Lāh min al-shaytān al-rajim);

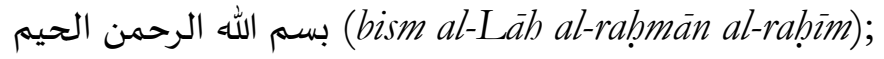

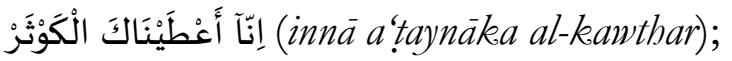

(fasalli lirabbika wanhar);

صباح الخير (șabāh al-khayr). 


\title{
DARI ISLAMISASI ILMU MENUJU PENGILMUAN ISLAM: MELAWAN HEGEMONI EPISTEMOLOGI BARAT
}

\author{
Ismail Thoib dan Mukhlis \\ (Fakultas Tarbiyah IAIN Mataram \\ Email: ismail_thoib@yahoo.com; dhani_care@yahoo.com)
}

Abstract: Islamization project as epistemological means of knowledge by Ismail R. al-Faruqi, focuses on Islamic disengagement spirit to pursue its science and technology backwardness. This research aims at analyzing the concept weaknesses and improves them. Methods employed are analyzing basic elements and characteristics of knowledge of which the Islamic label is considered inappropriate. The research findings suggest that the formulation of scientific Islam is considered more appropriate as this is where Islamic values become ethics not because of its Islamic label but its own value goodness.

Abstrak: Proyek islamisasi oleh Ismail R. al-Faruqi, sebagai saluran epistemologis untuk membaca yang berfokus pada semangat disengagement (tepatnya, kritis dan selektif) asupan dari Barat sebagai alat pengejar ketertinggalan sains dan teknologi barat masih menimbulkan perdebatan. Penelitian ini bertujuan mendeskripsikan titik-titik lemah Islamisasi Ilmu dan memperbaikinya dengan konsep pengilmuan Islam. Penerapan metode dilakukan lewat analisis elemen-elemen dan sifat dasar ilmu yang tidak memungkinkan label Islam dan mensyaratkan perbaikan terminologi. Temuan penelitian menyarankan formulasi pengilmuan Islam-oleh Kuntowijoyo, tempat nilai Islam menjadi baik bukan karena atribut Islamnya, akan tetapi karena kebaikan nilai itu sendiri.

Keywords: sekuler, Islamisasi Ilmu, al-Attas, epistemelogi, al-Faruqi, pengilmuan Islam, objektivasi. 
TIDAK diragukan lagi bahwa Dunia Islam berada di anak tangga paling bawah di antara penganut agama-agama besar. Negerinegeri Islam jauh tertinggal oleh Eropa Utara, Amerika Utara, Australia, dan Selandia Baru yang Protestan; oleh Eropa Selatan, dan Amerika Selatan yang Katolik Romawi; oleh Eropa Timur yang Katolik Ortodoks; oleh Israel yang Yahudi; oleh India yang Hindu; oleh Cina, Korea Selatan, Taiwan, Hongkong, dan Singapura yang Budhist-Konfusianis; oleh Jepang yang BudhistTaois, dan oleh Thailand yang Budhis. Praktis, tidak ada satu pun agama besar di bumi ini yang lebih rendah kemajuan ilmu pengetahuan dan teknologinya daripada umat Islam. ${ }^{1}$ Dalam kondisi seperti ini masyarakat Muslim melihat kemajuan Barat sebagai sesuatu yang mengagumkan. Hal ini menyebabkan sebagian kaum Muslim tergoda oleh kemajuan Barat dan berupaya melakukan reformasi dengan jalan Westernisasi.

Postur umat Islam yang demikian mengganggu para cendekiawan Muslim untuk mencari jalan keluar dari agitasi intelektual Barat yang ditengarai telah mencabut akar identitas keislaman dan pada sisi yang memekarkan dualisme, bahkan monolisme logosentris Barat; pembebek terbaik tanpa melakukan pengisolasian atas pelbagai tawaran konseptual Barat. Inferioritas diri ini semakin mengukuhkan miniatur the lack of vision kaum Muslim. ${ }^{2}$ Untuk menjawab dilema yang demikian Syed Muhammad Naquib al-Attas, 3 Ismail R. al-Faruqi, menawarkan proyek islamisasi sebagai saluran epistemologis untuk membaca Westernisasi secara cerdas sembari merelokasinya dengan semangat disengagement (tepatnya, kritis dan selektif) asupan dari Barat. Tapi gagasan ini bagi Kuntowijoyo, yang semula pendukung gagasan Islamisasi Ilmu justru memompa semangat ekslusivisme dengan pemiskinan hanya sebagai rahmat bagi umat Islam an sich. Ini, bagi Kuntowijoyo, 21.

${ }^{1}$ Nurcholish Madjid, Kaki Langit Peradaban (Jakarta: Paramadina, 2001), 1984).

${ }^{2}$ Ismail R. al-Faruqi, Islamisasi Ilmu Pengetabuan, (Bandung: Pustaka,

3Lihat, Wan Mohd Nor Wan Daud, The Educational Philosophy and Practice of Syed Muhammad Naquib al-Attas An Exposition of the Original Concept of Islamization (Kuala Lumpur: ISTAC, 1998), 237. 
menciderai semangat substantif Islam sebagai rahmat bagi apapun dan siapapun tanpa terjebak pada anatomi identitas Muslim atau nonmuslim. Untuk itu dia mengajak untuk meninggalkan Islamisasi Ilmu sembari menuntun kita menuju kapal selam yang bernama Pengilmuan Islam demi universalisme Islam sebagai rumah bersama umat manusia.

\section{Islamisasi Ilmu: Demi Identitas Keislaman}

Secara historis, ide atau gagasan Islamisasi Ilmu pengetahuan muncul pada saat diselenggarakan Konferensi Dunia Pertama tentang Pendidikan Islam di Mekah pada tahun 1977. Konferensi yang diprakarsai oleh King Abdul Aziz University ini berhasil membahas 150 makalah yang ditulis oleh sarjana-sarjana dari 40 negara, dan merumuskan rekomendasi untuk pembenahan serta penyempurnaan sistem pendidikan Islam yang diselenggarakan oleh umat Islam seluruh dunia. Salah satu gagasan yang direkomendasikan adalah menyangkut Islamisasi Ilmu pengetahuan. Gagasan ini antara lain dilontarkan oleh Syed Muhammad Naquib al-Attas dalam makalahnya yang berjudul "Preliminary Thoughts on the Nature of Knowledge and the Definition and the Aims of Education dan Ismail R. al-Faruqi dalam makalahnya "Islamicizing Social Science."4

Mengikuti logika sederhana, Islamisasi yang diartikan dengan mengislamkan ilmu, mengandung pemahaman bahwa ilmu yang berkembang pesat selama ini, lebih-lebih di Barat telah sesat sehingga perlu diislamkan. Suatu kenyataan, memang ada sebagian orang yang bersikap apriori setelah melihat fakta bahwa kemajuan ilmu pengetahuan tidak menjadikan Barat lebih beradab, bahkan Barat dinilai telah teralienasi oleh pengetahuan dan teknologinya. Ide Islamisasi Ilmu lahir seiring dengan berbagai keterpurukan dan ketimpangan yang mewarnai kehidupan umat manusia akibat terpisahnya ilmu dari agama, berupa perkembangan ilmu pengetahuan dan teknologi yang semakin canggih, namun rupanya kian mengabaikan nilai etis dan agama. Sebaliknya, agama yang tidak ditopang dengan ilmu

${ }^{4}$ Muhaimin, Arah Baru Pengembangan Pendidikan Islam, Pemberdayaan, Pengembangan kurikulum, hingga Redifinisi Islamisasi Pengetahuan (Bandung: Nuansa, 2003). 
pengetahuan disinyalir tidak layak jual di tengah masyarakat maju yang ilmiah minded.

Secara substansial proses Islamisasi Ilmu telah terjadi sejak masa Rasulullah Saw. Hal ini dapat kita lihat dari proses pengislaman yang dilakukan oleh Nabi Muhammad Saw. terhadap masyarakat Arab pada saat itu. Melalui ajaran-ajaran alQur'an, sebagai sumber hukum Islam pertama, beliau merubah seluruh tatanan Arab Jahiliyah kepada tatanan masyarakat Islam hanya dalam kurun waktu dua puluh tiga tahun. Dengan alQur'an, Muhammad Saw. merubah pandangan hidup mereka tentang manusia, alam semesta, dan kehidupan dunia. Pengislaman ilmu ini diteruskan oleh para sahabat, tabiin dan ulama-ulama sehingga umat Islam mencapai kegemilangan dalam ilmu. Dengan pengetahuan Islam yang mendalam, mereka menyaring filsafat Yunani Kuno untuk disesuaikan dengan pemikiran Islam. Sebagai hasilnya, ada hal-hal dari filsafat Yunani Kuno yang diterima dan ada juga yang ditolak. ${ }^{5}$

${ }^{5} \mathrm{Hal}$ ini dapat kita lihat dari proses pengislaman yang dilakukan oleh Nabi Muhammad saw terhadap masyarakat Arab pada saat itu. Melalui ajaran-ajaran al-Qur'an, sebagai sumber hukum Islam pertama, beliau merubah seluruh tatanan Arab Jahiliyah kepada tatanan masyarakat Islam hanya dalam kurun waktu 23 tahun. Dengan al-Qur'an, Muhammad Saw. merubah pandangan hidup mereka tentang manusia, alam semesta dan kehidupan dunia. Pengislaman ilmu ini diteruskan oleh para sahabat, tabi'in dan ulama-ulama sehingga umat Islam mencapai kegemilangan dalam ilmu. Pada "zaman pertengahan," Islamisasi juga telah dilakukan khususnya oleh para teolog Muslim seperti al-Gazālī, Fakhr al-Dīn al-Rāzi, Sayf al-Dīn, alAmīdiy, dan lain-lain. Dengan pengetahuan Islam yang mendalam, mereka menyaring filsafat Yunani Kuno untuk disesuaikan dengan pemikiran Islam. Sebagai hasilnya, ada hal-hal dari filsafat Yunani Kuno yang diterima dan ada juga yang ditolak. Proses penerjemahan mendapatkan sokongan yang besar dari pemerintah saat itu. Tunjuk misalnya, Dinasti Abbasiyah yang secara khusus mendirikan Bayt al-Hikmah untuk mengakomodir kepentingan ini. Bayt al-Hikmah atau Rumah Kearifan atau House of Wisdom, kata Hitti merujuk Ibn Nādhim dari al-Fihris, yang didirikan oleh al-Ma'mūn sebagai wujud ketertarikannya pada rasionalitas dan pengakuannya atas kesejalanan antara rasionalitas dengan ajaran agama. Terjemahan karya filsafat pertama yang patut dihargai berasal dari sastrawan terkemuka, 'Abd al-Lāh bin Muqaffā (w. 759 M.) dan putranya, Muhammad, yang mencakup Categories, Hermeneutica, dan Analytica apriora karya Aristoteles pada masa pemerintahan Khalifah al-Manșūr (w. 773 M.) dari Dinasti Abbasiyah. Selain daripada itu, 
Oleh karena itu, Islamisasi dalam arti kata yang sebenarnya bukanlah perkara baru bila ditinjau dari aspek yang luas ini.

ringkasan Galen atas karya Plato (Dialogue) yang berjudul Timaeus hingga karya-karya Aristoteles, seperti De anima, Book of Animals, Analytica apriora, Secret of the Secrets yang dikerjakan oleh Yahya bin al-Bițriq (w. 815 M.) pada masa pemerintahan Harūn al-Rashīd ( (w. 809 M.). Pemintalan karya-karya Yunani tersebut dilanjutkan oleh Al-Ma'mūn (w. 833 M.) yang menetapkan kebijakan resmi bagi aktivitas pengarapan karya-karya filsafat, sains, dan kedokteran Yunani dengan mendirikan lembaga Bayt al-Hikmah di Bagdad pada tahun 830 M. yang dipimpin oleh Yuhannā bin Maskawaih (w. 857 M.) yang kemudian digantikan oleh muridnya, Hunayn bin Isḥāq (w. 873 M.). Di antara karya filsafat terpenting yang dipercayakan kepada tim yang terdiri atas Hunayn, Hubays sepupu Hunayn, dan 'Īsa bin Yahyā murid Hunayn adalah Analytica posteriora karya Aristoteles, Synopsis of the Ethics karya Galen, dan sejumlah intisari dari karya-karya Plato seperti Sofist, Parmenides, Politicus, Republic, dan Laws. Karya-karya Aristoteles, seperti Categories, Hermeneutica, Generation and Corruption, Nicomachean Etbics, dan beberapa bagian dari buku Physics. Sementara itu, Metaphysics digarap oleh seorang penerjemah kurang terkenal bernama Asțāt (Eustathius) dan Yahyā bin 'Adī (w. 974 M.). Bagian lain dari buku Physics diterjemahkan oleh Qusțā bin Luqā (w. 912 M.) yang juga dipercaya menerjemahkan bagian-bagian dari Generation and Corruption. Abū Bisr Mattā (w. 940 M.) dan muridnya, Yahya bin 'Adī dipercaya menerjemahkan banyak karya yang umumnya dari bahasa Suryani, antara lain, Rhetoric dan Poetics karya Aristoteles. Kedua karya ini adalah bagian dari karya utama Aristoteles dalam logika yang dikenal sebagai Organon dalam tradisi Arab dan Suryani. al-Hasan bin Suwar (w. 1017 M.) dan Abū 'Uthmān al-Dimashqiy (w. 910 M.) adalah dua penerjemah yang cukup tersohor karena belakangan ikut andil dalam menggarap naskah-naskah logika dan filsafat Yunani. Beberapa paraphrase Enneads menjadi pijakan dasar bagi Neoplatonisme Islam-Arab diulas secara panjang lebar oleh sejumlah filosof Muslim termasuk al-Kindî, al-Farâbî, dan Ibn Sînâ. Namun, anehnya, tak satu pun dari mereka pernah mempersoalkan keaslian buku ini. Karya-karya lain yang diragukan sebagai karya Aristoteles, tetapi ikut diterjemahkan ke dalam bahasa Arab antara lain adalah De plantis, Book of Minerals, Liber de causis, yang dikenal juga dengan nama Pure Good, yang berisikan 32 proposisi pilihan dari Elemmentatio Theologia karya Proclus dari Athena (w. 485 M.), seorang Neoplatonik, yang diterjemahkan oleh seorang yang tidak dikenal. Lihat misalnya dalam, Mukhlis, Ngaji Bareng Filosof (Mataram: Alam Tara Institute-Nusatenggara Center, 2008); Majid Fakhry, Sejarah Filsfat Islam Sebuah Peta Kronologis, ter. Zaimul Am (Bandung: Mizan 2002); Oliver Leaman, Pengantar Filsafat Islam: Sebuah Pendekatan Tematis, ter. Musa Kazhim dan Arif Mulyadi (Bandung, Mizan 2002); Seyyed Hossein Nasr (ed.), Ensiklopedi Tematis Filsafat Islam, Jilid I dan II, ter. Tim Penerjemah Mizan (Bandung: Mizan, 2003) 
Hanya saja, secara operasional, istilah Islamisasi Ilmu baru dipopulerkan sebagai kerangka epistemologi baru oleh para pembaru Muslim pada tahun 70-an. Gagasan Islamisasi Ilmu di kalangan pemikir Muslim merupakan program epistemologi dalam rangka membangun (kembali) peradaban Islam. Hal ini disebabkan adanya perbedaan yang fundamental antara pandangan keilmuan dalam Islam dengan peradaban Barat pada tataran ontologi ${ }^{6}$ dan epistemologi. ${ }^{7}$

${ }^{6}$ Pada sisi ontologi, Barat modern hanya menjadikan alam nyata sebagai objek kajian dalam sains, sehingga pada gilirannya mereka hanya membatasi akal dan panca indra (empiris) sebagai epistemologinya. Hal itu tidaklah ganjil mengingat perkembangan ilmu dan dinamisasi peradaban di Barat bergeser dari satu titik ekstrem ke titik ekstrem lainnya. Baca misalnya dalam; Bernard Delfgauw, Filsafat Abad 20, ter. Soejono Soemargono (Yogyakarta: Tiara Wacana Yogyakarta, 1987); Bernhard Rensch, Biophilosphy (New York: Columbia University Press, 1971); Bertrand Russell, Sejarah Filsafat Barat, ter. Sigit Jatmiko et.al. (Yogyakarta: Pustaka Pelajar, 2002); Brinton Christopher Wolff, A History of Civillization 1715 to the Present (New Jersey: Prentice-Hall INC, 1962).

${ }^{7}$ Sejarah pertentangan antara gerejawan dengan ilmuan; pergumulan yang tak harmonis melibatkan pemuka agama Kristen dengan para saintis di Eropa pada Abad Pertengahan (Dark Age) telah melahirkan desakan pencerahan pemikiran yang dikenal dengan Renaissance/Enlightenment/ Aufklarung, masing-masing di Italia, Prancis, Inggris, dan Jerman. Keterkungkungan kaum gerejawan yang dianggap menghambat perkembangan ilmu pengetahuan dengan mengimani Bible yang telah banyak diselewengkan, hingga inkuisisi Galileo Galilea yang berpandangan Heliosentris (matahari sebagai pusat tata surya) dan bukan sebagaimana diyakini pemuka gereja yang Geosentris (bumi yang menjadi pusat tata surya), justru dijawab para ilmuwan Barat di masa pencerahan dengan "sekularisasi". Mereka menanggalkan agama karena agama dianggap telah menghadang perkembangan sains dan pengetahuan. Inilah yang dimaksud dengan perpindahan dari satu titik ekstrem ke titik ekstrem lainnya tadi. Akibatnya epistemologi Barat modern-sekuler melahirkan faham-faham semisal eksistensialisme, materialisme, ateisme, empirisme, rasionalisme, kapitalisme, liberalisme, sosialisme, humanisme, relativisme, agnostisme, dan sebagainya. Hal itu bermula ketika Bapak filsafat modern—René Descartes (m. 1650)—memformulasi sebuah prinsip "aku berfikir maka aku ada" (cogito ergo sum). Dengan prinsip ini, Descartes telah menjadikan rasio sebagai satusatunya kriteria untuk mengukur kebenaran. Penekanan terhadap rasio dan panca indera sebagai sumber ilmu juga dilakukan oleh para filosof lain seperti Thomas Hobbes (m. 1679), Benedict Spinoza (m. 1677), John Locke (m. 1704), George Berkeley (m. 1753), Francois-Marie Voltaire (m. 1778), 
Para cendekiawan yang terlibat dalam proyek Islamisasi Ilmu seperti Syed Muhammad Naquib al-Attas,${ }^{8}$ selanjutnya disebut

Jean-Jacques Rousseau (m. 1778), David Hume (m. 1776), Immanuel Kant (m. 1804), Georg Friedrick Hegel (m. 1831), Arthur Schopenhauer (m. 1860), Soren Kierkegaard (m. 1855), Edmund Husserl (m. 1938), Henri Bergson (m. 1941), Alfred North Whitehead (m. 1947), Bertrand Russell (m. 1970), Martin Heidegger (m. 1976), Emilio Betti (m. 1968), Hans-Georg Gadamer, Jurgen Habermas, dan lain-lain. Epistemologi Barat modernsekular telah menyebabkan teologi Kristen menjadi sekular. Jika pada zaman pertengahan, para teolog Kristen seperti Santo Augustinus (m. 430), Boethius (m. 524), Johannes Scotus Erigena (m. 877), Santo Anselm (m. 1109), Santo Bonavantura (m. 1274) dan Santo Thomas Aquinas (m. 1274) memodifikasi filsafat Yunani kuno supaya sesuai dengan teologi Kristen, maka kini pada abad ke-20, para teolog Kristen seperti Karl Barth (18861968), Dietrich Bonhoeffer (1906-1945), Friedrich Gogarten (1887-1967), Paul van Buren (m. 1998), Thomas Altizer, Gabriel Vahanian, William Hamilton, Woolwich, Werner and Lotte Pelz, Harvey Cox dan lain-lain memodifikasi teologi Kristen supaya sesuai dengan peradaban Barat modern-sekular. Mereka menegaskan, ajaran Kristiani harus disesuaikan dengan pandangan-hidup sains modern yang sekular. Mereka harus menafsirkan kembali ajaran agama Kristen supaya tetap relevan dengan perkembangan kehidupan masyarakat modern yang sekular. Bertrand Russell, Sejarah Filsafat Barat: Kaitannya dengan Kondisi Sosio-Politik Zaman Kuno bingga Sekarang ter. Sigit Jatmiko et.al., (Yogyakarta: Pustaka Pelajar, November 2002); Ahmad Tafsir, Filsafat Umum: Akal dan Hati sejak. Thales sampai James (Bandung: Remaja Rosdakarya, 1994); K. Bertens, Ringkasan Sejarah Filsafat (Yogyakarta: Kanisius, 1998); Richard Osborne, Filsafat Untuke Pemula ter. P. Hardono Hadi (Yogyakarta: Kanisius, 2001); Dava Sobel, Putri Sang Galileo: Kisah Sejati tentang Pergulatan Agama, Sains, dan Cinta (Bandung: Mizan, 1999); David J. Bosch, Transformasi Misi Kristen: Sejarah Teologi Misi yang Mengubah dan Berubah, ter. Stephen Suleman (Jakarta: BPK Gunung Mulia, 1999); E. Haeis Harbison, The Age of Reformation (New York: Cornell University Press, 1956); Francois Furent, \& Denis Richet, Revolusi Perancis (Yogyakarta: Gadjah Mada University Press, 1989); Jacob Burckhardt, The Civilization of the Renaissans in Italy (New York: 1953).

${ }^{8}$ Syed Muhammad Naquib al-Attas adalah seorang cendekiawan Muslim Malaysia yang dikenal sangat kritis kepada Barat. Ia lahir di Bogor, Jawa Barat, pada tanggal 5 September 1931, dan menempuh pendidikannya di The Royal Military Academy, Sandhurst, Inggris (1952-1955). Setelah itu ia melanjutkan pendidikannya di University of Malaya, Singapura (1957-1959), meraih master di McGill University, Montreal, Canada (1962), dan Ph.D. di Univesity of London, London, Inggris (1965) dengan konsentrasi bidang Islamic philosophy, theology dan metaphisycs. Al-Attas dikenal sebagai pelopor konseptualisasi Universitas Islam, yang ia formulasikan pertama kalinya pada 
al-Attas, menyadari bahwa virus yang terkandung dalam Ilmu Pengetahuan Barat modern-sekuler merupakan tantangan yang paling besar bagi kaum Muslimin saat ini. ${ }^{9}$ Dalam pandangannya, peradaban Barat modern telah membuat ilmu menjadi problematis. Selain telah salah memahami makna ilmu, peradaban Barat juga telah menghilangkan maksud dan tujuan ilmu. ${ }^{10}$ Sekalipun peradaban Barat modern juga menghasilkan ilmu yang bermanfaat, namun peradaban tersebut juga telah menyebabkan kerusakan dalam kehidupan manusia. Dalam pandangan al-Attas, Westernisasi ilmu adalah hasil dari kebingungan dan skeptisisme. Westernisasi ilmu telah mengangkat keraguan dan dugaan ke tahap metodologi ilmiah. Bukan hanya itu, Westernisasi ilmu juga telah menjadikan keraguan sebagai alat epistemologi yang sah dalam keilmuan. Menurutnya lagi, Westernisasi ilmu tidak dibangun di atas wahyu dan kepercayaan agama, namun dibangun di atas tradisi budaya yang diperkuat dengan spekulasi filosofis yang terkait dengan

saat acara First World Conference on Muslim Education, di Makkah (1977). Pada tahun 1987, ia mewujudkan gagasannya dengan mendirikan The International Institute of Islamic Thought and Civilization (ISTAC). Ia merancang dan membuat sendiri arsitektur komplek bangunan ISTAC, merancang kurikulum, dan membangun perpustakaan ISTAC yang kini tercatat sebagai salah satu perpustakaan terbaik di dunia dalam bidang Islamic studies.

${ }^{9}$ Dari kedua makalah ini, gagasan tentang Islamisasi Ilmu pengetahuan menjadi tersebar luas ke masyarakat Muslim dunia. Pihak pro maupun kontra-pun bermunculan. Di antara tokoh yang mendukung "pro" terhadap proyek islamisasi tersebut antara lain adalah Seyyed Hossein Nasr (1933), Ziauddin Sardar (1951) dan beberapa tokoh lain yang menolak adanya Westernisasi ilmu. Seyyed Hossein Nasr menolak sains Barat modern dan mengusulkan scientia sacra sebagai alternatif dalam karyanya Knowledge and the Sacred (Pakistan: Suhail Academy Lahore, 1988). Sedangkan Ziauddin Sardar dan teman-temannya membentuk Gagasan Idjmali (Idjmali Idea). Lihat dalam bukunya Adnin Armas, Krisis Epistemologi dan Islamisasi Ilmu (ISID Gontor: Center for Islamic \& Occidental Studis, 2007), 10. Sedangkan pihak yang menentang "kontra" terhadap gagasan islamisasi ini yaitu beberapa pemikir Muslim kontemporer seperti Fazlur Rahman, Muhsin Mahdi, Abdus Salam, Abdul Karim Soroush, dan Bassam Tibi.

${ }^{10}$ Uraian menarik tentang hal ini dapat dilacak dalam; Mulyadhi Kartanegara, Pengantar Epistemologi Islam (Bandung: Mizan, 2003); Mulyadhi Kartanegara, Menyibak Tirai Kejahilan: Pengantar Epistemologi Islam (Bandung: Mizan, Juni 2003). 
kehidupan sekular yang memusatkan manusia sebagai makhluk rasional. Akibatnya, ilmu pengetahuan dan nilai-nilai etika dan moral yang diatur oleh rasio manusia terus menerus berubah. AlAttas bercita-cita ingin menjadikan peradaban Islam kembali hidup dan memiliki pengaruh yang mewarnai peradaban global umat manusia. Karena itu, seluruh hidupnya ia persembahkan bagi upaya-upaya revitalisasi peradaban Islam, agar nilai-nilai yang di masa lalu dapat membumi dan menjadi ikon kebanggaan umat Islam, dapat menjelma dalam setiap lini kehidupan kaum Muslim sekarang ini. ${ }^{11}$

Menurut al-Attas, Islamisasi Ilmu adalah "The liberation of man first from magical, mythological, animistic, national-cultural tradition, and then from secular control over his reason and his language" (Islamisasi adalah pembebasan manusia, pertama dari tradisi tahayul, mitos, animisme, kebangsaan dan kebudayaan dan setelah itu pembebasan akal dan bahasa dari pengaruh sekularisme). ${ }^{12}$ Sedangkan yang kedua adalah pembebasan jiwa manusia dari sikap tunduk kepada keperluan jasmaninya yang condong menzalimi dirinya sendiri, sebab sifat jasmaniahnya lebih condong untuk lalai terhadap fitrahnya sehingga mengganggu keharmonian dan kedamaian dalam dirinya yang pada gilirannya menjadi jahil tentang tujuan asalnya. Jadi Islamisasi bukanlah satu proses evolusi (a process of evolution) tetapi satu proses pengembalian kepada fitrah (original nature). ${ }^{13}$

Menurut al-Attas, ilmu pengetahuan tidak bersifat netral dan bebas nilai. Sehingga ketika ilmu berkembang di sebuah wilayah, ilmu tersebut dibentuk berdasarkan nilai-nilai budaya, ideologi, dan agama yang dianut oleh para pemikir dan ilmuan di wilayah tersebut. Kemudian terjadilah apa yang disebut sebagai Helenisasi Ilmu, Kristenisasi Ilmu, Islamisasi Ilmu pada masa klasik Islam, kemudian Westernisasi ilmu dalam bentuk sekularisasi oleh masyarakat Barat terhadap ilmu. Oleh karena itu proses "Islamisasi" oleh Mulyadhi Kartanegara, adalah suatu

${ }^{11}$ Lihat definisi Syed Muhammad Naquib al-Attas mengenai 'Peradaban Barat' dalam karyanya Islam and Secularism (Kuala Lumpur: ISTAC, 1993), 135.

${ }^{12}$ Ibid., 44.

${ }^{13}$ Ibid. 
bentuk "naturalisasi" ilmu dalam rangka meminimalisir dampak negatif sains sekuler terhadap kepercayaan agama. ${ }^{14}$ Menurut alAttas, ada lima faktor yang menjiwai budaya dan peradaban Barat: (1) akal yang diandalkan untuk membimbing kehidupan manusia; (2) bersikap dualistik terhadap realitas dan kebenaran; (3) menegaskan aspek eksistensi yang memproyeksikan pandangan hidup sekuler; (4) membela doktrin humanisme; (5) menjadikan drama dan tragedi sebagai unsur-unsur yang dominan dalam fitrah kemanusiaan. ${ }^{15}$

Kelima unsur tersebut di atas, menurut al-Attas, harus diisolir dari setiap bidang ilmu pengetahuan modern saat ini, khususnya dalam ilmu pengetahuan humaniora. Sedangkan dalam ilmu-ilmu alam, fisika dan aplikasinya harus diislamkan juga, khususnya dalam penafsiran-penafsiran akan fakta-fakta dan dalam formulasi teori-teori. Setelah unsur-unsur patogen (asing) bagi doktrin Islam tersebut diisolir, al-Attas kemudian menyarankan agar unsur dan konsep utama Islam yang terdiri dari konsep: manusia, din, 'ilm dan ma'rifah, hikmah, 'adl, 'amaladab, dan konsep universalitas (kulliyah-jam'iyyah) diserapkan ke dalam konsep ilmu pengetahuan kontemporer. Kesemua unsur tersebut ditambatkan pada konsep tauhid, syari'ah, sunnah, dan tarikh.

Kelima hal di atas, merupakan prinsip-prinsip utama dalam pengembangan keilmuan di Barat, yang dinilai bertentangan dengan nilai-nilai Islam. Supaya umat Islam terhindar dari prinsip-prinsip yang menjebak di atas, maka ada empat poin yang harus diperhatikan seorang Muslim dalam mengembangkan ilmu pengetahuan, yaitu: (1) prinsip-prinsip utama Islam sebagai intisari peradaban Islam; (2) pencapain sejarah kebudayaan Islam sebagai manifestasi ruang dan waktu dari prinsip-prinsip utama Islam; (3) bagaimana kebudayaan Islam dibandingkan dan dibedakan dengan kebudayaan lain dari sudut manifestasi dan intisari; (4) bagaimana kebudayaan Islam menjadi pilihan yang

${ }^{14}$ Mulyadhi Kartanegara, Menyibak Tirai Kejahilan: Pengantar Epistemologi Islam (Bandung: Mizan, Juni 2003).

15Syed Muhammad Naquib al-Attas, Prolegomena to the Metaphysics of Islam: An Exposition of the Fundamental Elements of the Worldview of Islam (Kuala Lumpur: ISTAC, 1995), 88- 108. 
paling bermanfaat berkaitan dengan masalah-masalah pokok Islam dan non Islam di dunia saat ini.

Renungan ini sangat penting, karena apabila kita memperhatikan secara cermat, pengalaman masa lampau serta rencana masa depan menuju satu arah perubahan yang diinginkan, maka harus dimulai dari rumusan sistem pendidikan yang paripurna. Jika proses penyerapan nilai-nilai tersebut sudah dilakukan, maka proses Islamisasi ini akan membebaskan manusia dari tradisi magik, mitologik, animisme, tradisi budaya nasional yang bertentangan dengan Islam, dan kemudian dari kontrol sekuler kepada akal dan bahasanya. Islamisasi akan membebaskan akal manusia dari keraguan (shakk), dugaan (zann) dan argumentasi kosong (mira) menuju keyakinan akan kebenaran mengenai realitas spiritual, intelligible, dan materi. Islamisasi akan mengeluarkan penafsiran-penafsiran ilmu pengetahuan kontemporer dari ideologi, makna dan ungkapan sekuler. ${ }^{16}$

Islamisasi pengetahuan yang ditawarkan tidak semata berupa pelabelan sains dengan ayat-ayat al-Qur'an atau hadis yang dipandang relevan dengan penemuan ilmiah, tetapi beroperasi pada level epistemologis, di mana dilakukan "dekonstruksi" terhadap epistemologi Barat yang berkembang sekarang dan kemudian "merekontruksi" epistemologi alternatif dengan meramu secara kritis bahan-bahan yang ada pada "tradisi intelektual Muslim" yang telah dibina selama lebih dari satu millenium oleh para filosof dan ilmuan klasik. Menurut Mulyadhi, konstruksi ulang epistemologi ini akan meliputi pembahasan status ontologis obyek ilmu, klasifikasi, dan metodologi ilmu. Ilmu pengetahuan kontemporer bisa diislamkan dengan cara menafsirkan kembali fakta-fakta penemuannya menurut pandangan dunia (worldview) Islam yang termaktub dalam al-Qur'an dan dengan menjuruskan kembali program-program penelitian sains dan teknologi serta ilmu humaniora demi memenuhi kepentingan "maqạsid al-shari"ah". Karena pada hakekatnya metodologi yang terkandung dalam "maqāsid al-shari"ah" dapat mengakomodir secara penuh tujuan-

16Wan Daud, Wan Mohd Nor, Filsafat dan Praktik Pendidikan Islam Syed M. Naquib al-Attas, ter. Hamid Fahmy, et.al., (Bandung: Mizan, 2004), 312. 
tujuan riset ilmiah, sepanjang ilmu dipahami sebagai sesuatu yang tidak netral dan tidak bebas nilai. Bagi al-Attas, proyek "Islamisasi Ilmu' pengetahuan adalah yang bersifat "darüriyyat", karena apabila tidak segera diislamkan, maka anomali yang timbul dari pengetahuan Barat yang sekularistik akan mengancam eksistensi agama, keturunan dan harga diri umat Islam.

Selain al-Attas, cendekiawan Muslim yang memiliki gagasan yang bernas tentang Islamisasi Ilmu adalah seorang filosof Palestina bernama Ismail Al-Faruqi ${ }^{17}$ pada tahun 1982 dengan

${ }^{17}$ Ismail Raji al-Faruqi lahir di Yaifa (Palestina) pada tanggal 1 Januari 1921 dan meninggal dunia pada tanggal 24 Mei 1986. Pendidikan dasarnya dilalui di College Des Frese, Libanon sejak 1926 sampai 1936. Kemudian dia memperoleh gelar BA pada tahun 1941 di The American University, Beirut. Sedangkan gelar masternya diraih di Indiana dan pada tahun 1952 dia mencapai gelar doktoral (Ph.D.) dari Universitas Indiana, Harvard. Meskipun al-Faruqi berhasil menyelesaikan gelar doktoral dalam filsafat Barat, dikarenakan langkanya kesempatan kerja dan juga dorongan batin, membawanya kembali ke akar dan warisan kecendekiawanan islamnya. Dia meninggalkan Amerika menuju Kairo. Ismail R. al-Faruqi memulai karir profesionalnya sebagai guru besar sudi Islam pada Institut Pusat Riset Islam di Karachi dari tahun 1961 sampai 1963. Selama setahun berikutnya setelah dia kembali ke Amerika, al-Faruqi menjadi guru besar tamu dalam bidang sejarah agama di Universitas Chicago. Pada tahun 1964, al-Faruqi memperoleh posisi permanen penuh pertamanya sebagai Guru Besar Luar Biasa di Jurusan Agama pada Universitas Syracuse. Dia akhirnya pindah ke Universitas Temple pada tahun 1968 untuk menjadi guru besar studi Islam dan sejarah agama. Ini adalah posisi yang didudukinya sampai dia wafat pada tahun 1986. Selain mengajar, al-Faruqi juga mendirikan International Institute of Islamic Thought (IIIT) pada 1980 di Amerika Serikat, sebagai bentuk nyata gagasan Islamisasi Ilmu Pengetahuan. Kini lembaga tersebut memiliki banyak cabang di berbagai Negara, termasuk di Indonesia dan Malaysia. Sebelumnya pada tahun 1972, al-Faruqi telah mendirikan The Association of Muslim Social Scientist. Kedua lembaga yang didirikannya itu menerbitkan jurnal Amerika tentang Ilmu-ilmu sosial Islam. Selama hidupnya, al-Faruqi telah menulis banyak tulisan, baik di majalah ilmiah maupun populer, dan juga buku. Lebih dari dua puluh buku dalam berbagai bahasa telah ditulisnya, dan tidak kurang dari seratus artikel telah dipublikasikan. Seluruh tulisannya pada dasarnya adalah gagasan-gagasan cerah dan teorinya untuk memperjuangkan proyek integrasi ilmu, yang dikemas dalam bingkai besar Islamisasi Ilmu pengetahuan. Beberapa karyanya adalah sebagai berikut: Christian Ethics: A Systematic and Historical Analysis of Its Dominant Ideas, The 
bukunya yang berjudul "Islamization of Knowledge". Dia mengatakan bahwa jika kita menggunakan alat, kategori, konsep, dan model analisis yang diambil murni dari Barat sekuler, seperti Marxisme, maka semua itu tidak relevan dengan ekologi dan realitas sosial negara Islam, sehingga tidak mampu beradaptasi dengan nilai-nilai Islam, bahkan akan berbenturan dengan etika Islam itu sendiri. Karena itu, dalam pandangannya, pertentangan antara ulama tradisional dan para tokoh reformasi dalam membangun masyarakat Muslim dengan ilmu modern dan kategori profesional tidak akan terlaksana tanpa dibarengi dengan usaha keras menerapkan etika Islam dalam metodologi para filosof Muslim awal. Karena itu, dia menganjurkan agar melakukan revisi terhadap metode-metode itu dengan menghadirkan kembali dan mengintegrasikan antara metode ilmiah dengan nilai-nilai Islam. Bagi al-Faruqi, dalam pendefinisian atau pengertian tentang Islamisasi Ilmu pengetahuan, dia menjelaskan bahwa pengertian dari Islamisasi Ilmu yaitu sebagai usaha untuk memfokuskan kembali ilmu yaitu, untuk mendefinisikan kembali, menyusun ulang data, memikir kembali argumen dan rasionalisasi yang berhubungan dengan data itu, menilai kembali kesimpulan dan tafsiran, membentuk kembali tujuan dan disiplin itu ditujukan memperkaya visi dan perjuangan Islam. ${ }^{18}$

Islamisasi Ilmu pengetahuan itu sendiri berarti melakukan aktivitas keilmuan seperti mengungkap, menghubungkan, dan menyebarluaskannya manurut sudut pandang ilmu terhadap alam kehidupan manusia. Menurut aI-Faruqi, Islamisasi Ilmu pengetahuan berarti mengislamkan ilmu pengetahuan modern dengan cara menyusun dan membangun ulang sains sastra, dan

Great Asian Religions, Sources of slamic Thought: Three Epistles on Tawhid by Muhammad ibn 'Abd al Wahhab, Islam and Culture, Islamic Thought and Culture, Islamization of Knowledge, Tawhid: Its Implications For Thought And Life dan lainnya. Ramayulis dan Syamsul Nizar, Ensiklopedi Tokoh Pendidikan Islam, Mengenal Tokoh Pendidikan Islam di Dunia Islam dan di Indonesia (Ciputat: Quantum Teaching, 2005). John L.Esposito-John O Voll, Tokoh-tokoh Kunci Gerakan Islam Kontemporer (Jakarta: Raja Grafindo Persada, 2002).

${ }^{18}$ Rosnani Hasim, Gagasan Islamisasi Ilmu Pengetahuan Kontemporer: Sejarah, Perkembangan, dan Arah Tujuan”, Islamia, Tahun II No. 6 Juli-September, 2005), 35-6. 
sains-sains ilmu pasti dengan memberikan dasar dan tujuantujuan yang konsisten dengan Islam. Setiap disiplin harus dituangkan kembali sehingga mewujudkan prinsip-prinsip Islam dalam metodologinya, dalam strateginya, dalam data-datanya dan problem-problemnya. Seluruh disiplin harus dituangkan kembali sehingga mengungkapkan relevansi Islam yang bersumber pada tauhid. ${ }^{19}$

Menurut al-Faruqi, Islamisasi Ilmu pengetahuan modern merupakan "satu tugas yang serupa sifatnya dengan tugas yang pernah dimainkan oleh nenek moyang kita yang mencerna ilmu zaman mereka dan mewariskan kepada kita peradaban dan kebudayaan Islam, walaupun ruang lingkupnya kini lebih luas". Gagasan tersebut dianggap sangat beralasan karena al-Qur'an sejak pertama kali turun sudah melakukan pembebasan secara epistemologis terhadap konsep ilmu. Sebagaimana argumen Wan Mohd Nor Wan Daud bahwa konsep "Islamisasi Ilmu" pengetahuan kontemporer secara sistematik adalah hasil dari separuh kedua abad XX, namun ayat-ayat terawal yang diturunkan kepada Nabi Muhammad, dalam Qs. al-'Alaq (96):15 menyiratkan dengan jelas semangat Islamisasi pengetahuan. ${ }^{20}$

Pandangan al-Faruqi berkenaan dengan langkah-langkah dalam Islamisasi Ilmu pengetahuan, dia mengemukakan ide Islamisasi Ilmunya berlandaskan pada esensi tauhid yang memiliki makna bahwa ilmu pengetahuan harus mempunyai kebenarannya. Al-Faruqi menggariskan beberapa prinsip dalam pandangan Islam sebagai kerangka pemikiran metodologi dan cara hidup Islam. Prinsip-prinsip tersebut ialah:

a. Keesaan Allah.

b. Kesatuan alam semesta.

c. Kesatuan kebenaran dan kesatuan pengetahuan ${ }^{21}$

Menurut al-Faruqi, kebenaran wahyu dan kebenaran akal itu tidak bertentangan tetapi saling berhubungan dan keduanya saling melengkapi. Karena bagaimanapun, kepercayaan

${ }^{19}$ Ismail Raji al-Faruqi. Islamisasi Ilmu pengetahuan, ter. Anas Mahyuddin (Bandung: Pustaka, 1984).

${ }^{20}$ Wan Mohd Nor Wan Daud, "Epistemologi Islam dan Tantangan Pemikiran Ummat”, dalam Islamia, Tahun II. No. 5, Jakarta: 2005.

21 al-Faruqi, Islamisasi..., 20. 
terhadap agama yang ditopang oleh wahyu merupakan pemberian dari Allah dan akal juga merupakan pemberian dari Allah yang diciptakan untuk mencari kebenaran. Syaratsyarat kesatuan kebenaran menurut al-Faruqi yaitu: pertama, kesatuan kebenaran tidak boleh bertentangan dengan realitas sebab wahyu merupakan firman dari Allah yang pasti cocok dengan realitas. Kedua, kesatuan kebenaran yang dirumuskan, antara wahyu dan kebenaran tidak boleh ada pertentangan, prinsip ini bersifat mutlak. Dan ketiga, kesatuan kebenaran sifatnya tidak terbatas dan tidak ada akhir. Karena pola dari Allah tidak terhingga, oleh karena itu diperlukan sifat yang terbuka terhadap segala sesuatu yang baru. ${ }^{22}$

d. Kesatuan hidup

e. Kesatuan umat manusia.

Islam menganjurkan kebebasan dalam hubungannya dengan kemanusiaan tanpa batas-batas yang senantiasa menghampiri mereka. Dalam konteks ilmu pengetahuan, nampak bahwa keinginan al-Faruqi, ilmuwan beserta penemuannya, hendaknya memberi kesejahteraan kepada umat manusia tanpa memandang etnis. Ketaqwaan yang dipergunakan oleh Islam yang membebaskan dari belenggu himpitan dunia hendaknya menjadi landasan bagi para ilmuan.

Al-Faruqi juga menawarkan suatu rancangan kerja sistematis yang menyeluruh untuk program Islamisasi Ilmu pengetahuannya yang merupakan hasil dari usahanya selama bertahun-tahun melaksanakan perdebatan-perdebatan dan diskusi-diskusi melalui sejumlah seminar internasional yang diselenggarakan. Rencana kerja al-Faruqi untuk program Islamisasi mempunyai lima sasaran yaitu: pertama, menguasai disiplin-disiplin modern. Kedua, menguasai khazanah Islam. Ketiga, menentukan relevansi Islam yang spesifik pada setiap bidang ilmu pengetahuan modern. Keempat, mencari cara-cara untuk melakukan sintesa kreatif antara khazanah Islam dengan ilmu pengetahuan modern. Dan kelima, mengarahkan pemikiran Islam ke lintasan-lintasan yang mengarah pada pemenuhan pola rancangan Allah. ${ }^{23}$

\author{
22 Ibid. \\ 23Ibid., h. 5
}


Menurut al-Faruqi, sasaran di atas bisa dicapai melalui dua belas langkah sistematis yang pada akhirnya mengarah pada Islamisasi Ilmu pengetahuan, yaitu: pertama, penguasaan terhadap disiplin-disiplin modern. Kedua, peninjauan disiplin ilmu modern. Ketiga, penguasaan ilmu warisan Islam yang berupa antologi. ${ }^{24}$ Keempat, penguasaan ilmu warisan Islam yang berupa analisis. Kelima, penentuan relevansi Islam yang spesifik untuk setiap disiplin ilmu. Relevansi ini, kata al-Faruqi, dapat ditetapkan dengan mengajukan tiga persoalan yaitu: a) Apa yang telah disumbangkan oleh Islam, mulai dari al-Qur'an hingga pemikiran-pemikiran kaum modernis, dalam keseluruhan masalah yang telah dicakup oleh disiplin-disiplin modern; b) Seberapa besar sumbangan itu jika dibandingkan dengan hasilhasil yang telah diperoleh oleh disiplin-disiplin tersebut; c) Apabila ada bidang-bidang masalah yang sedikit diperhatikan atau bahkan sama sekali tidak diabaikan oleh ilmu warisan Islam, ke arah mana kaum Muslim harus mengusahakan untuk mengisi kekurangan itu, juga memformulasikan masalah-masalah, dan memperluas visi disiplin tersebut. Kemudian yang keenam, penilaian kritis terhadap disiplin modern. Ketujuh, penilaian krisis terhadap khazanah Islam. Kedelapan, survei mengenai problemproblem terbesar umat Islam. Kesembilan, survei mengenai problem-problem umat manusia. Kesepuluh, analisa dan sintesis kreatif. Kesebelas, merumuskan kembali disiplin-disiplin ilmu dalam kerangka kerja (framework) Islam. Kedua belas, penyebarluasan ilmu pengetahuan yang sudah diislamkan. Selain langkah tersebut, alat-alat bantu lain untuk mempercepat islamisasi pengetahuan adalah dengan mengadakan konferensikonferensi dan seminar untuk melibatkan berbagai ahli di bidang-bidang illmu yang sesuai dalam merancang pemecahan masalah-masalah yang menguasai antar disiplin. Para ahli yang terlibat harus diberi kesempatan bertemu dengan para staf pengajar. Selanjutnya pertemuan-pertemuan tersebut harus menjajaki persoalan metode yang diperlukan. ${ }^{25}$ 


\section{Pengilmuan Islam: Demi Universalisme Islam}

Upaya Islamisasi dianggap merupakan agenda besar guna mendekatkan kembali ilmu pengetahuan dengan Islam. Namun, wacana tersebut menyulut perdebatan yang serius antara dua alur mainstream; pro dan kontra. Salah satu reasoning yang biasa diajukan oleh para penyangga Islamisasi Ilmu bahwa kebenaran wahyu bersifat mutlak, sedangkan kebenaran rasio bersifat relatif sehingga rasio harus tunduk pada wahyu. Pernyataan ini seakanakan mengandaikan wahyu yang termaktub dalam al-Qur'an dapat mengungkapkan dirinya sendiri sehingga manusia hanyalah sebagai agen pasif yang begitu saja menerima pengetahuan darinya. Jamak diketahui, Islamisasi Ilmu selalu mengobarkan semangat kembali ke al-Qur'an dan hadis dan dengan meletakkannya sebagai sumber pengetahuan. Alasannya, selain sebagai pedoman hidup kaum Muslim, di dalamnya juga banyak ditemukan banyak ayat yang berbicara tentang fenomena alam dan kemanusiaan. Dengan demikian, al-Qur'an benarbenar menyediakan dirinya sebagai muara dari segala ilmu pengetahuan. Atau setidaknya, Islamisasi Pengetahuan meletakkan al-Qur'an sebagai konsep dasar (baca: inspirasi) yang dikembangkan melalui riset ilmiah.

Sebaliknya, mereka yang menolaknya berargumen bahwa ilmu pengetahuan bersifat obyektif, dan karenanya selalu netral, seperti dalam konsep netralitas etik. Gugatan dari kelompok yang menolak Islamisasi Ilmu itu menyodorkan persoalan seperti bagaimana memberi label matematika yang Islam. Adakah perbedaan arkeologi Islam dan arkeologi non-Islam? 26 Pertanyaan-pertanyaan problematik seperti ini tampaknya menjadi landasan kritik terhadap gagasan "Islamisasi Pengetahuan". Menyikapi hal ini, Fazlur Rahman berpendapat bahwa pengetahuan tidak bisa diislamkan karena tidak ada yang salah di dalam ilmu pengetahuan, masalahnya hanya dalam menyalahgunakan. Bagi Fazlur Rahman, ilmu pengetahuan memiliki dua kualitas, seperti "Pisau bermata dua" yang harus

26Imam Suprayogo, "Membangun Integrasi Ilmu dan Agama", dalam Zainal Abidin Bagir et. all., Integrasi Ilmu dan Agama: Interpretasi dan Aksi (Bandung: Mizan, 2005), 214. 
digunakan dengan penuh kehati-hatian dan bertanggungjawab, sekaligus sangat penting menggunakannya secara benar ketika memperolehnya. ${ }^{27}$

Pada umumnya para pengkritik Islamisasi Ilmu berpendapat bahwa sains adalah mengkaji fakta-fakta objektif dan independen dari manusia di mana budaya dan agama harus dipisahkan dari nilai-nilai. Abdus Salam, misalnya mengatakan hanya ada satu sains universal, problem-problemnya dan bentukbentuknya adalah internasional dan tidak ada sesuatu seperti sains Islam, sebagaimana tidak ada sains Hindu, sains Yahudi, atau sains Kristen. ${ }^{28}$ Mengikuti Abdus Salam, Pervez Hoodbhoy, juga menyatakan bahwa tidak ada sains Islam tentang dunia fisik, dan usaha untuk menciptakan sains Islam merupakan pekerjaan sia-sia, sebagaimana telah diungkap Sir Syed Ahmed Khan, bahwa tujuan agama lebih pada usaha meningkatkan moralitas ketimbang menjelaskan fakta-fakta sains. ${ }^{29}$ Kritik terhadap Islamisasi Pengetahuan juga diajukan oleh Abdul Karim Soroush. Abdul Karim Soroush juga mengajukan kritik terhadap konsep Islamisasi Ilmu. Ia menyimpulkan bahwa Islamisasi Ilmu pengetahuan adalah tidak logis atau tidak mungkin (the impossibility or illogicality of Islamization of knowledge). Alasannya, realitas bukan Islami atau tidak Islami. Kebenaran yang ada di dalamnya juga bukan ditentukan apakah ini Islami atau tidak Islami. Oleh sebab itu, sains sebagai proposisi yang benar, bukan Islami atau tidak Islami. Para filosof Muslim terdahulu tidak pernah menggunakan istilah filsafat Islam. Istilah tersebut adalah label yang diberikan oleh Barat (a western coinage). Ringkasnya, dalam mengkritik konsep Islamisasi Ilmu pengetahuan ini, Soroush menyatakan; (1) metode metafisis, empiris atau logis adalah independen dari Islam atau agama apa pun. Metode tidak bisa diislamkan; (2) Jawaban-jawaban yang benar tidak bisa

${ }^{27}$ Sebagaimana dikutip Adnin Armas, "Westernisasi dan Islamisasi Ilmu”, dalam Majalah Islamia. Tahun 01. No. 6/Juli-September 2005, 15.

28Sebagaimana dikutip Rosnani Hashim, "Gagasan Islamisasi Ilmu Pengetahuan Kontemporer". dalam Majalah Islamia, Tahun 01. No. 6/JuliSeptember 2005, 35.

${ }^{29}$ Pervez Hoodbhoy, Ikhtiar Menegakkan Rasionalitas, ter. Sari Meutia (Bandung: Mizan, 1996), 138. 
diislamkan. Kebenaran adalah kebenaran itu sendiri dan tidak bisa diislamkan; (3) Pertanyaan dan masalah yang diajukan dalam sains adalah untuk mencari kebenaran, meskipun diajukan oleh nonmuslim; (4) Metode yang digunakan dalam sains juga tidak bisa diislamkan. ${ }^{30}$

Tapi beberapa kritikan yang dilontarkan oleh para cendekiawan di atas pun tidak kurang reaksioner serta emosional dengan para pendulu proyek Islamisasi, namun sayangnya para pengkritik ini gagal meletakkan landasan serta gagasan yang tandas sebagai jalan lain untuk mengeluarkan dari dilema Islamisasi Ilmu, dan pada sisi lain hegemoni peradaban Barat. Adalah Kuntowijoyo 31 yang merampungkan payung epistemologis untuk keluar dari ekslusivisme baju Islamisasi Ilmu. Di pengantar bukunya, secara tegas Kuntowijoyo

${ }^{30}$ Lihat Armas, "Westernisasi..., 16.

${ }^{31}$ Kuntowijoyo lahir pada tanggal 18 September 1943. Setelah menyelesaikan SMA di Surakarta tahun 1962, Kuntowijoyo melanjutkan pendidikannya di Jurusan Sejarah, Fakultas Sastra, Universitas Gadjah Mada, dan selesai tahun 1969. Sebelumnya, dia menyelesaikan studi S-2 di The University of Connecticut, Amerika Serikat, tahun 1974. Disertasinya di Universitas Columbia, Social Change in an Agrarian Society: Madura 1950-1940, sudah diterjemahkan ke dalam bahasa Indonesia. Dengan kapasitasnya, doktor ilmu sejarah dari Columbia University ini, di Amerika Serikat, dijuluki sebagai seorang sejarawan beridentitas paripurna. Karena memang, dia menjalani hidup di beragam habitat dan identitas. Dia guru besar sejarah di Universitas Gadjah Mada. Beberapa bukunya yang mendapat acungan jempol dari berbagai kalangan intelektual seperti Paradigma Islam: Interpretasi untuk. Aksi (1991), Metodologi Sejarah (1994), dan Radikalisme Petani (1993), Demokrasi dan Budaya (1994), Pengantar Ilmu Sejarah (1995), dan Identitas Politike Umat Islam (1997). Di luar sebagai penulis buku-buku serius, Kuntowijoyo juga seorang penulis non-fiksi; cerita pendeknya, Dilarang Mencintai BungaBunga (1968), memenangkan penghargaan pertama dari sebuah majalah sastra. Kemudian kumpulan cerpennya yang diberi judul sama, Dilarang Mencintai Bunga-Bunga, mendapat Penghargaan Sastra dari Pusat Bahasa (1994). Anjing-Anjing Menyerbu Kuburan, mendapat penghargaan sebagai cerpen terbaik versi Harian Kompas berturut-turut pada 1995, 1996, dan 1997. Novel dengan judul Pasar meraih hadiah Panitia Hari Buku, 1972. Naskah dramanya berjudul Rumput-Rumput Danau Bento (1968) dan Topeng Kayu (1973) mendapatkan penghargaan dari Dewan Kesenian Jakarta. Kuntowijoyo meninggal dunia pada hari Selasa, 22 Pebruari 2005 di usia 62 tahun. M. Fahmi, Islam Transendental: Menelusuri Jejak-jejak Pemikiran Kuntowijoyo, (Yogyakarta: Pilar Religia, 2005). 
mengatakan, “... gerakan intelektual Islam harus melangkah ke arah Pengilmuan Islam. Kita harus meninggalkan Islamisasi Pengetahuan....". 32 Permasalahan dari Islamisasi Pengetahuan bagi Kuntowijoyo adalah bagaimana kedudukan pengetahuan dalam Islam, bukankah pengetahuan adalah kebudayaan dan kebudayaan adalah muamalah. Karena mua'malah maka rumusannya adalah "Semuanya boleh kecuali yang dilarang". Jika pengetahuan sudah sangat egoistik (secara berlebihan) mengklaim kebenaran maka statusnya tidak lagi sebagai muamalah. Kuntowijoyo menyanggah gagasan Islamisasi Ilmu pengetahuan lantaran mengingkari objektivasi ilmu. Menurutnya, ilmu pengetahuan yang benar-benar objektif tidak perlu diislamkan sebab Islam mengakui objektivitas. Suatu teknologi, akan tetap sama saja di tangan orang Islam ataupun non Islam. Asumsi inilah yang mendasari Kuntowijoyo untuk lebih memilih konsep Pengilmuan Islam daripada Islamisasi Ilmu.

Islam mengakui objektivitas, maka ilmu yang benar-benar objektif tidak perlu diislamkan, suatu teknologi akan sama ditangan orang Islam atau orang kafir. Metode dimanapun sama, apakah itu metode survey, metode partisipan, atau metode grounded dapat dipakai dengan aman tanpa resiko bertentangan dengan keimanan. Maka tidak perlu ada kekhawatiran pada ilmuilmu yang benar-benar objektif dan sejati. Untuk ilmu yang benar-benar objektif kiranya sangat bergantung pada niat individu, maka niat individu itu yang memerlukan Islamisasi bukan ilmunya.

Secara harfiah, frasa "Pengilmuan Islam" berarti menjadikan Islam sebagai ilmu. Dengan "Pengilmuan Islam", yang ingin ditujunya adalah aspek universalitas klaim Islam sebagai rahmat bagi alam semesta-bukan hanya bagi pribadi-pribadi atau masyarakat Muslim, tapi semua orang; bahkan setiap makhluk di alam semesta ini. "Rahmat bagi alam semesta" adalah tujuan akhir pengilmuan Islam. Rahmat itu dijanjikan bukan hanya untuk Muslim tapi untuk semuanya. Tugas Muslim adalah mewujudkannya; pengilmuan Islam.

${ }^{32}$ Kuntowijoyo, Islam Sebagai Ilmu: Epistemologi, Metodologi, dan Etika (Bandung: Teraju, 2004), 1. 


\title{
Pengilmuan Islam dicoba dipahami dengan
} membandingkannya dengan Islam sebagai mitos dan ideologi. Untuk lebih jauh memahami ini dalam konteks yang lebih luas, kita bisa melihat alternatif lain bagi gerakan Pengilmuan Islam. Dalam konteks yang berbeda, Kuntowijoyo membandingkan pengilmuan Islam dengan kodifikasi Islam dan Islamisasi Ilmu. ${ }^{33}$ Pengilmuan Islam (yang dalam konteks ini disebutnya sebagai demistifikasi Islam) adalah gerakan dari teks ke konteks; Islamisasi adalah sebaliknya, dari konteks ke teks; sementara kodifikasi berkutat di sekitar eksplorasi teks, nyaris tanpa memperhatikan konteks. Ketiga gerakan ini adalah ragam perwujudan dari keinginan untuk kembali kepada teks (al-Qur'an dan Sunnah). Islamisasi Ilmu, menurutnya, lebih bersikap reaktif, yaitu reaksi terhadap bangunan keilmuan yang sudah wujud, yang dipandang tak sesuai dengan nilai-nilai Islam, dan ingin dikembalikan kepada Islam yang lebih dipahami sebagai teks. ${ }^{34}$

Satu cara untuk memahami gerak Pengilmuan Islam adalah dengan memperhatikan periodesasi sistem pengetahuan Muslim yang dibuat Kuntowijoyo. 35 Periodesasi penting untuk memahami apa yang akan dikerjakan pada suatu periode tertentu. Keputusan baik yang diambil di suatu periode belum tentu akan bermanfaat di periode yang lain. Dalam periodisasi ini, umat Islam bergerak dari periode pemahaman Islam sebagai mitos, lalu sebagai ideologi, dan terakhir sebagai ilmu.

Periode pertama, Islam sebagai mitos. Islam sebagai mitos dipahami sebagai sesuatu yang sudah selesai dan tinggal perlu dipertahankan, dijaga kemurniannya dari campuran-campuran non Islami, dan jika perlu dipertahankan dari serangan pihak luar. Karenanya Kuntowijoyo menyebut bahwa tradisi ini biasanya bersifat deklaratif atau apologetis. ${ }^{36}$ Sebuah indikasi menarik yang diajukan Kuntowijoyo adalah mengenai maraknya buku-buku jenis itu yang diterbitkan Bina Ilmu atau Gema Insani Press.

\author{
${ }^{33}$ Ibid., 6-11. \\ ${ }^{34}$ Ibid., 8. \\ 35Ibid., 80-1. \\ 36Kuntowijoyo, Muslim Tanpa Masjid (Bandung: Mizan, 2001), 102-3.
}


Periode kedua, Islam sebagai ideologi. Islam sebagai ideologi sudah bersifat lebih rasional, tapi masih terlalu apriori/nonlogis. Di sini Islam ditampilkan sebagai ideologi tandingan bagi ideologi-ideologi dunia seperti kapitalisme dan komunisme. Dalam konteks ini, Islam eksis hanya jika ia eksis secara institusional-formal. Karena itu, ketika di Indonesia semua ormas diharuskan berasas Pancasila, ini dipahami sebagai upaya de-Islamisasi. Padahal, kata Kuntowijoyo, ini juga bisa dilihat sebagai isyarat bahwa Islam perlu memasuki babak baru, yaitu periode Islam sebagai ilmu.

Dalam periode ilmu, yang diperlukan adalah objektivikasi Islam. Dapat dikatakan bahwa dengan melakukan objektivikasi, "baju Islam" ("Islam sebagai baju") ditanggalkan, dan Islam secara substansial tampil secara universal. Nilai-nilai Islami menjadi sesuatu yang bisa diterima orang, Muslim ataupun nonMuslim, karena kebaikan nilai-nilai itu sendiri, bukan karena nilai-nilai itu disebut "Islami". Dengan cara ini, Islam menjadi rahmat untuk alam semesta.

Namun ini mensyaratkan bahwa agama lebih dulu diobjektivikasi, agar ia benar-benar bermanfaat untuk seluruh umat manusia, tak hanya memenuhi keinginan eksklusif sebagian kaum beragama tertentu untuk menegaskan identitasnya. Persis itulah yang menjadi salah satu tujuan objektivikasi, yaitu untuk menghindari dominasi satu kelompok agama atas kelompokkelompok lainnya. ${ }^{37}$ Dengan ini, Muslim masih dapat tetap menjadikan al-Qur'an sebagai sumber hukum. Namun, "Objektivikasi Islam akan menjadikan al-Qur'an terlebih dahulu sebagai hukum positif, yang pembentukannya atas persetujuan bersama warga negara." 38 Muslim tak dapat serta merta menerapkan syariah menjadi hukum negara, misalnya, tapi itu hanya dapat dilakukan jika ada kesepakatan dari semua, termasuk non-Muslim. Ini hanya bisa dicapai jika nilai-nilai Islam itu telah diobjektivikasi sehingga tampil sebagai nilai-nilai yang dapat diterima semua orang lepas dari latar belakang/sumber nilai-nilai itu.

${ }^{37}$ Kuntowijoyo, Islam..., 65.

${ }^{38}$ Ibid., 66. 
Sesungguhnya, Kuntowijoyo juga menyarankan bahwa semua agama melakukan hal yang sama, objektivikasi. ${ }^{39}$ Jika demikian, ini akan menjamin bahwa konflik dapat dihindari. Islam-dan sesungguhnya semua agama-bukan lagi berwujud identitas atau simbol yang diterjemahkan dalam label-label institusional yang menarik garis antara kelompokku dan kelompokmu, tapi justru ditransformasikan menjadi sumber pemecahan masalah bersama secara objektif. Kalaupun, misalnya, partai Islam atau partai Kristen ingin didirikan, perjuangannya tak lagi bersifat partisan. Nilai-nilai agama tertentu bisa diusung dalam agenda perjuangannya, tapi sebagai nilai-nilai yang kebaikannya bersifat objektif, bisa dipahami semua orang. Gagasan-gagasan normatif Islam ditampilkan sebagai nilai-nilai universal, bersifat publik, dan dijustifikasi secara rasional. Nilai-nilai tersebut layak diterima bukan karena ia berasal dari Islam; berasal dari Islam atau tidak, itu tak penting lagi. Yang penting adalah bahwa nilai-nilai itu bisa ditunjukkan sebagai mengandung kebaikan pada dirinya sendiri, sehingga sumber nilai-nilai itu menjadi tak penting; yang penting adalah kemampuan menjustifikasinya secara rasional, demi mempersuasi sebanyak mungkin orang untuk menerimanya.

Sebagai hasilnya, "Meyakini latar belakang agama yang menjadi sumber ilmu atau tidak, tidak menjadi masalah, ilmu yang berlatar belakang agama adalah ilmu yang objektif, bukan agama yang normatif." 40 Objektivikasi ilmu adalah ilmu dari orang beriman untuk seluruh manusia, tanpa mengenal agamanya, non-agama, bahkan anti agama. "Pendeknya, dari orang beriman untuk seluruh manusia." $41 \mathrm{Hal}$ yang persis sama berlaku untuk agama-agama lain, yang bagi Kuntowijoyo juga perlu melakukan objektivikasi agar manfaatnya dirasakan semua orang. Ini karena ia tampak yakin benar bahwa semua agama memiliki keberpihakan pada nilai-nilai kemanusiaan universal yang serupa. Untuk itu, Kuntowijoyo menjustifikasi dengan: “... Kitab Suci yang satu tidak lebih tinggi daripada Kitab Suci lainnya. Islam mengajarkan tentang adanya kalimah sawa' (titik

\footnotetext{
${ }^{39}$ Ibid., 67.

${ }^{40}$ Ibid., 57.

${ }^{41}$ Ibid., 58.
} 
temu, konsensus, common denominator). ${ }^{42}$ Tidak ada pertentangan tentang hal-hal yang fundamental, meskipun ada perbedaan dalam detailnya.

Untuk melengkapi objektivikasi di atas, Kuntowijoyo juga melengkapi piranti Pengilmuan Islam dengan integralisasi. Integralisasi adalah penyatuan ilmu-ilmu yang terlahir dari akal budi manusia dengan al-Qur'an atau wahyu. ${ }^{43}$ Pengilmuan Islam memiliki sikap yang lebih terbuka dalam hal ini. Gerakan ini dengan rendah hati mengakui bahwa penggagasnya lahir di alam ilmu-ilmu sekular, yang terkadang tampak bermusuhan dengan agama. Sementara umat beriman mungkin memiliki keberatan terhadap sebagian bangunan ilmu kontemporer, namun mereka tak ingin menggantikan ilmu-ilmu sekular. ${ }^{44}$ Jadi, di satu sisi yang diinginkan oleh Kuntowijoyo adalah melanjutkan perjalanan ilmu-ilmu sekuler dan mencoba memperbaiki dari dalam. Pencapaian ilmu-ilmu sekuler tidak dinafikan, tapi diintegrasikan dalam suatu kerangka teoretis baru yang punya keberpihakan cukup jelas kepada nilai-nilai humanisasi/emansipasi, liberasi, dan transendensi. ${ }^{45}$ Kuntowijoyo menjelaskan, bahwa dalam ilmu-ilmu yang terlahir dari akal budi manusia (ilmu sekuler) diawali dengan filsafat, antroposentrisme, diferensiasi, hingga menjadi ilmu sekular. Filsafat adalah awal berangkat ilmu-ilmu sekuler. Rasionalisme yang berkembang pada abad XV-XVI M menolak teosentrisme abad pertengahan; wahyu dibuang, sementara rasio diagungkan.

Antroposentrisme adalah konsekuensi logis dari penolakan atas wahyu di mana manusia menjadi pusat kebenaran, etika, kebijaksanaan, dan pengetahuan. Manusia adalah pencipta, pelaksana, dan sekaligus konsumen atas produksinya sendiri. Waktu manusia memandang dirinya sebagai pusat, maka terjadilah diferensiasi (pemisahan). Seluruh pengetahuan dipisahkan dari wahyu. Karena itu kegiatan ekonomi, politik, hukum, dan ilmu pengetahuan dipisahkan dari agama (sekular). Kebenaran ilmu terletak pada ilmu sendiri. Maka jadilah apa

${ }^{42}$ Qs. Ali 'Imran (3): 64.

${ }^{43}$ Kuntowijoyo, Islam..., 49.

${ }^{44}$ Ibid., 53.

${ }^{45}$ Qs. Ali Imran (3): 110. 
yang dinamakan dengan ilmu sekular, ilmu yang diklaim sebagai objektif, bebas nilai, dan bebas dari kepentingan. Namun ternyata, ilmu itu telah melampaui dirinya. Ilmu yang semula adalah ciptaan manusia berbalik menjadi penguasa atas manusia. Ilmu menggantikan wahyu sebagai pedoman kehidupan. ${ }^{46}$

Dalam upaya integralisasi, perlu adanya pembalikan. Sumber pertama pengetahuan dan kebenaran haruslah agama, kemudian bergerak menjadi teoantroposentrisme, dediferensiasi, dan ilmu integralistik. Penjelasannya adalah, pertama, sumber pengetahuan dan kebenaran adalah dari agama, dalam hal ini adalah wahyu Tuhan, yaitu al-Qur'an. Kemudian, di dalam teoantroposentrisme, kebenaran agama digabungkan dengan kebenaran yang bersumber dari akal budi manusia. Sehingga dalam praktiknya, terjadi dediferensiasi, yaitu menyatunya agama dalam setiap aktivitas kehidupan, baik politik, ekonomi, hukum, ataupun budaya. Selanjutnya dikenal apa yang dinamakan dengan ilmu integralistik, ilmu yang bukan sekedar menggabungkan, tetapi juga menyatukan antara wahyu dan hasil akal budi manusia. ${ }^{47}$

Kuntowijoyo meyakini bahwa wahyu al-Qur'an memiliki signifikansi dalam membangun keilmuan yang integralistik dan menghilangkan pandangan yang dikotomis tentang bidangbidang ilmu. Paradigma ini dinilai memiliki prospek yang kuat dalam melahirkan konsep-konsep dan temuan-temuan keilmuan yang relevan dengan realitas dan kebutuhan umat, serta dalam memecahkan setiap persoalan kemanusiaan dan dalam upaya menjaga eksistensi alam dan seisinya. Prospek ini akan semakin optimal, apabila terus dibangun kolaborasi yang integral antara tiga macam ayat Tuhan (qawliyyah, kawniyyah, insaniyyah). Konsepsi paradigma keilmuan Islam yang integralistik, yang ditawarkan Kuntowijoyo ini, telah memperlebar peta pemikiran intelektual Muslim dalam upaya mengembangan ilmu di dunia Islam, sekaligus merupakan bantahan terhadap kritikan yang menolak penggunaan al-Qur'an di luar kajian ilmu-ilmu agama.

Paradigma Pengilmuan Islam diderivasi dari semangat alQur'an: "Kamu adalah umat terbaik, yang dilabirkan untuk manusia, menyuruh kepada yang ma'rüf, dan mencegah dari yang munkar, dan

\footnotetext{
46 Kuntowijoyo, Islam..., 52.

${ }^{47}$ Ibid., 55.
} 
beriman kepada Allah". ${ }^{48}$ Menurut Kuntowijoyo ada empat hal yang tersirat dalam ayat tersebut, pertama, khayr ummab; konsep umat yang terbaik bagi Islam merupakan mengerjakan ketiga hal tersebut dalam ayat bukanlah sekedar hadiah dari Tuhan. Tetapi konsep umat yang terbaik ini merupakan tantangan agar aktif dan bekerja keras dalam sejarah. Kedua, ukbrijat li al-nās, aktivisme sejarah merupakan bentuk kerja keras di tengah umat manusia dan keterlibatan umat Islam dalam menentukan sejarah. Sebagaimana dalam ajaran Islam yang menekankan bahwa Islam merupakan agama amal, jadi pengetahuan yang didapatkan harus ditransformasikan bukan hanya untuk diri tetapi untuk orang lain. Ketiga, pentingnya kesadaran. Kesadaran dalam Islam merupakan bentuk kesadaran yang berbeda dengan Marxisme. Bentuk kesadaran dalam Islam nilai-nilai Ilahiah menjadi tumpuan dalam melakukan aktivisme sejarah. Kesadaran tersebut bersifat independensi yang bertumpu pada Tuhan bukan kepada struktur atapun kepada manusia. Kesadaran yang ditekankan pada struktur atau individu menjadikan bentuk kesadaran dalam Marxisme maka yang terjadi merupakan dalam bentuk individualisme, eksistensialisme, kapitalisme, dan liberalisme. Keempat, tetang etika profetik yang dapat dilakukan oleh siapa saja. Etika profetik merupakan pelaksanaan secara integral dari "ta'murüna bi al-ma'rüf wa tanhawna 'an al-munkar, wa tu'minüna bi al-Lāh", yang oleh Kuntowijoyo diterjemahkan menjadi; humanisasi (ta'murüna bi al-ma'rüf), liberasi (wa tanhawna 'an al-munkar), dan trasendensi (wa tu'minüna bi al-Läb). ${ }^{49}$

Humanisasi (ta'murūna bi al-ma'rüf). Humanisasi merupakan semangat dari peradaban Barat yang percaya pada the idea of progress, demokrasi, HAM, Liberalisme, kebebasan, kemanusiaan, kapitalisme, dan selfnees. Humanisasi merupakan proses pemanusiaan manusia dalam bahasa agamanya mengembalikan posisi manusia pada fitrahnya. Proses humanisasi merupakan jawaban dari patologi masyarakat modern yang mengalami dehumanisasi yang diakibatkan oleh kemajuan teknologi dan informasi. Manusia terjerat dengan teknologi sehingga manusia mengabdi untuk teknologi, bukannya teknologi yang mengabdi

${ }^{48}$ Qs. Ali Imran (3): 110.

${ }^{49}$ Qs. Ali Imran (3): 110. 
kepada manusia. Manusia pada masyarakat modern dengan kerangka pikir rasional teknokratis, menjadi manusia satu dimensi, jatuh dalam dataran kehinaan dan menghilangnya sisi atau dimensi manusia yang lain. Oleh karena itu, Kuntowijoyo mencoba melakukan humanisasi yang berdasar kepada agama, dimana merujuk iman dan amal soleh. Hal ini seperti diungkapkan dalam Qs. al-Tin (95): 5-6 bahwa "Manusia jatuh ke dalam tempat keterhinaan, kecuali orang-orang yang beriman dan beramal shaleh". Pengembalian kemuliaan manusia yang terjatuh pada kehinaan dengan mengembalikan manusia pada fitrahnya, dapat memenuhi semua dimensi yang dimiliki oleh manusia. Pemenuhan semua dimensi yang ada pada manusia ini, menjadikan posisi manusia tidak seperti masyarakat modern yang menafikan salah satu dimensi yang ada pada manusia. Humanisme ini merupakan pengkritisian humanisme Barat (bumanisme antroposentris), yang menyebabkan majunya peradaban Barat tetapi sekarang mereka mengalami dehumanisasi. Humanisme yang ditawarkan oleh Kuntowijoyo adalah humanisme yang didasarkan pada agama yakni humanisme teoantroposentris.

Liberasi (wa tanhawna 'an al-munkar). Liberasi yang ditawarkan oleh Kuntowijoyo paling tidak empat ranah seperti bidang ekonomi, sosial, budaya, dan politik dalam ranah sistem ilmu pengetahuan. Liberasi sistem ilmu pengetahuan dapat membebaskan manusia dari sistem pengetahuan materialis dan dominasi struktur. Hal ini, Islam memandang kesetaraan antara laki-laki dan perempuan. Liberalisasi dari sistem sosial budaya merupakan transformasi sosial umat Islam yang berkembang dari masyarakat agraris menuju masyarakat industri. Liberasi dalam ekonomi bagaimana menciptakan suatu sistem ekonomi yang bercorak keadilan, hal ini dikarenakan adanya kesenjangan ekonomi. Penggagasan tentang keadilan ekonomi merupakan nilai-nilai yang ada dalam ajaran Islam. Hal ini sebagaimana telah diungkapkan dalam Qs. al-Hashr, (59); 7, "Supaya barta tidak hanya beredar diantara orang-orng yang kaya diantara kamu". Selanjutnya dalam Qs. al Zukhruf, (43): 32, "Apakah mereka yang berhak membagi-bagi rahmat Tuhanmu?" Liberalisme dalam politik membebaskan dari sistem perpolitikan yang tidak adil dan 
terjadinya penindasan seperti sistem otoritarianisme, diktator, dan neofeodalisme.

Transendensi (wa tu'minūna bi al-Läb). Transendensi merupakan kunci beriman kepada Allah, yang menjadi ruh alam humanisasi dan liberasi dalam melihat dan pengaplikasian dari Pengilmuan Islam. Menurut Kuntowijoyo agar umat Islam meletakkan Allah sebagai pemengang otoritas, Tuhan yang maha objektif. Trasendensi yang dimaksudkan oleh Kuntowijoyo merupakan penggunaan wahyu sebagai salah satu unsur dalam ilmu. Paradigma wahyu digunakan dalam ilmu yang dilakukan oleh Kuntowijoyo melalui objektivikasi terhadap ayat-ayat al-Qur'an agar kebenaran yang didalamnya dapat diterima oleh seluruh manusia. Objektivikasi merupakan konkretisasi dalam kenyakinan internal, perbuatan ini dapat objektif jika dapat dirasakan oleh non Muslim sebagai suatu yang natural atau wajar, tidak sebagai perbuatan keagamaan. ${ }^{50}$

\section{Catatan Akhir}

Gagasan Islamisasi Ilmu Pengetahuan muncul sebagai gerakan sistematik untuk keluar dari dogmatisme-hegemonik epistemologis Barat dari sudut pandang Islam. Alasannya, tantangan terbesar yang dihadapi kaum Muslimin adalah ilmu pengetahuan modern yang tidak netral dan telah diinfus ke dalam praduga-praduga agama, budaya, dan filosofis, yang sebenarnya berasal dari refleksi kesadaran dan pengalaman manusia Barat. Oleh karena itu, ilmu pengetahuan modern harus diislamkan. Mengislamkan ilmu bukanlah pekerjaan mudah seperti labelisasi. Selain itu, tidak semua dari Barat berarti ditolak. Sebabnya, terdapat sejumlah persamaan antara Islam dan filsafat dan sains Barat. Oleh sebab itu, seseorang yang mengislamkan ilmu, ia perlu memenuhi pra-syarat, yaitu ia harus mampu mengidentifikasi pandangan-hidup Islam (the Islamic worldview) sekaligus mampu memahami budaya dan peradaban Barat. Ilmu pengetahuan kontemporer bisa diislamkan dengan cara mentafsirkan kembali fakta-fakta penemuannya menurut pandangan dunia (worldview) Islam yang

${ }^{50}$ Kutowjoyo, Identitas Politik Umat Islam (Bandung: Mizan, 1997). 
termaktub dalam al-Qur'an dan dengan menjuruskan kembali program-program penelitian sains dan teknologi serta ilmu humaniora demi memenuhi kepentingan "maqāsid al-shari"ah". Dengan demikian, umat Islam dapat keluar dari jebakan dilema epistemologis yang ditinggalkan oleh Barat dan demi ortodoksi nilai Islam.

Tapi skema Islamsasi Ilmu terkesan simplistis dan eksklusif oleh karena keberpihakannya yang kaku terhadap umat Islam sehingga terbaca hanya memayungi umat Islam dan memandang sumber nilai dan etika hanya milik Islam yang konsekuensinya adalah 'dari Islam, oleh Islam, dan untuk Islam'. Lantas bagaimana dengan the others, dalam artian yang bersumber dari luar Islam? Untuk menjawab dilema ini Kuntowijoyo menyodorkan formulasi Pengilmuan Islam sehingga Islam dapat eksis tanpa harus memakai baju Islam. Pengilmuan Islam dengan teori objektivikasi ilmu yang dituntut oleh Kuntowijoyo lewat pengilmuan Islamnya membuat baju dan atribut Islam yang melekat pada sistem, siyasiyah, dan objek lain harus dilepaskan. Nilai Islam menjadi baik bukan karena atribut Islamnya, akan tetapi karena kebaikan nilai itu sendiri. Ilmu pun dilepaskan dari label Islam, namun Islamlah yang ditarik dalam lingkaran keilmuan, sehingga kebaikan yang ditimbulkan oleh ilmu bukan karena label Islamnya, namun karena disesuaikannya Ilmu dengan nilai-nilai keIslaman. Ia adalah suatu tindakan yang didasarkan oleh nilai-nilai agama, disublimasikan dalam suatu tindakan objektif, sehingga diterima semua orang. Tujuannya adalah untuk semua orang, melintasi batas-batas agama, budaya, suku, dan lain-lain. Dengan demikian, Islam menjadi nilai dan etika, worldview tanpa harus tahu bahwa itu adalah Islam. Dengan demikian, Islam menjadi rumah bersama dan atau rahmat peradaban umat manusia. Wa al-Lāh a lam bi al-sawāb.

\section{Daftar Pustaka}

Armas, Adnin. "Westernisasi dan Islamisasi Ilmu", dalam Majalah Islamia. Tahun 01. No. 6/Juli-September 2005. al-Attas, Syed Muhammad Naquib. 1993. Islam and Secularism Kuala Lumpur: ISTAC. 
. 1995. Prolegomena to the Metaphysics of Islam: An

Exposition of the Fundamental Elements of the Worldview of Islam. Kuala Lumpur: ISTAC.

Bagir, Zainal Abidin. "Pengilmuan Islam", Makalah Dipresentasikan dalam Diskusi Sehari tentang Pemikiran Kuntowijoyo, Diselenggarakan Masyarakat Yogyakarta untuk Ilmu dan Agama (MYIA) dan Badan Koordinasi Mahasiswa Sejarah (BKMS) UGM, 26 Mei 2005.

Bosch, David J. 1999. Transformasi Misi Kristen: Sejarah Teologi Misi yang Mengubah dan Berubah, ter. Stephen Suleman. Jakarta: BPK Gunung Mulia.

Daud, Wan Mohd Nor Wan. "Epistemologi Islam dan Tantangan Pemikiran Ummat", dalam Islamia, Tahun II. No. 5, Jakarta, 2005.

- 1998. The Educational Philosophy and Practice of Syed Mubammad Naquib al-Attas An Exposition of the Original Concept of Islamization. Kuala Lumpur: ISTAC.

Delfgaauw, Bernard. 1987. Filsafat Abad 20, ter. Soejono Soemargono. Yogyakarta: Tiara Wacana Yogyakarta.

Esposito, John L. \& John O Voll. 2002 Tokoh-tokoh Kunci Gerakan Islam Kontemporer. Jakarta: Raja Grafindo Persada.

Fahmi, M. 2005. Islam Transendental: Menelusuri Jejak-jejak Pemikiran Kuntowijoyo. Yogyakarta: Pilar Religia.

Fakhry, Majid. 2002. Sejarah Filsfat Islam Sebuah Peta Kronologis, ter. Zaimul Am. Bandung: Mizan.

al-Faruqi, Ismail Raji. 1984. Islamisasi Ilmu pengetahuan, ter. Anas Mahyuddin. Bandung: Pustaka.

Furent, Francois \& Denis Richet. 1989. Revolusi Perancis. Yogyakarta: Gadjah Mada University Press.

Harbison, E. Haeis. 1956. The Age of Reformation. New York: Cornell University Press.

Hashim, Rosnani. "Gagasan Islamisasi Ilmu Pengetahuan Kontemporer". dalam Majalah Islamia, Tahun 01. No. 6/JuliSeptember 2005.

Hoodbhoy, Pervez. 1996. Ikhtiar Menegakkan Rasionalitas, ter. Sari Meutia. Bandung: Mizan.

Kartanegara, Mulyadhi. 2003. Menyibak Tirai Kejabilan: Pengantar Epistemologi Islam. Bandung: Mizan. 
Mizan.

. 2003. Pengantar Epistemologi Islam. Bandung:

Kuntowijoyo. 1991. Paradigma Islam: Interpretasi untuk Aksi. Bandung: Mizan.

. 1994. Dinamika Sejarab Umat Islam di Indonesia.

Yogyakarta: Pustaka Pelajar.

Mizan. . 1997. Identitas Politik Umat Islam. Bandung: 2001. Muslim Tanpa Masjid. Bandung: Mizan. . 2004. Islam Sebagai Ilmu: Epistemologi, Metodologi, dan Etika. Bandung: Teraju. . 'Islam Sebagai Ide", Prisma, No. Ekstra, 1984.

Leaman, Oliver. 2002. Pengantar Filsafat Islam: Sebuah Pendekatan Tematis, ter. Musa Kazhim dan Arif Mulyadi. Bandung, Mizan.

Madjid, Nurcholish. 2001. Kaki Langit Peradaban. Jakarta: Paramadina.

Muhaimin. 2003. Arah Baru Pengembangan Pendidikan Islam, Pemberdayaan, Pengembangan kurikulum, bingga Redifinisi Islamisasi Pengetahuan. Bandung: Nuansa.

Mukhlis. 2008. Ngaji Bareng Filosof. Mataram: Alam Tara Institute-Nusatenggara Center.

Nasr, Seyyed Hossein (ed.). 2003. Ensiklopedi Tematis Filsafat Islam, Jilid I dan II, ter. Tim Penerjemah Mizan. Bandung: Mizan.

Osborne, Richard. 2001. Filsafat Untuk Pemula terj. P. Hardono Hadi. Yogyakarta: Kanisius.

Ramayulis dan Syamsul Nizar. 2005. Ensiklopedi Tokoh Pendidikan Islam, Mengenal Tokoh Pendidikan Islam di Dunia Islam dan di Indonesia. Ciputat: Quantum Teaching.

Rensch, Bernhard. 1971. Biophilosphy. New York: Columbia University Press.

Russell, Bertrand. 2002. Sejarah Filsafat Barat, ter. Sigit Jatmiko et.al. Yogyakarta: Pustaka Pelajar. 2002. Sejarah Filsafat Barat: Kaitannya dengan Kondisi Sosio-Politik Zaman Kuno bingga Sekarang. terj. Sigit Jatmiko et.al. Yogyakarta: Pustaka Pelajar. 
Sobel, Dava. 1999. Putri Sang Galileo: Kisah Sejati tentang Pergulatan Agama, Sains, dan Cinta. Bandung: Mizan.

Suprayogo, Imam. 2005. "Membangun Integrasi Ilmu dan Agama", dalam Zainal Abidin Bagir et. all., Integrasi Ilmu dan Agama: Interpretasi dan Aksi. Bandung: Mizan.

Tafsir, Ahmad. 1994. Filsafat Umum: Akal dan Hati sejak Thales sampai James. Bandung: Remaja Rosdakarya.

Wolff, Brinton Christopher. 1962. A History of Civillization 1715 to the Present. New Jersey: Prentice-Hall INC. 